\title{
P02.88. Powdered Red Yeast Rice and Plant Stanols and Sterols to lower cholesterol
}

\author{
J Feuerstein ${ }^{1 *}$, W Bjerke ${ }^{2}$ \\ From International Research Congress on Integrative Medicine and Health 2012 \\ Portland, Oregon, USA. 15-18 May 2012
}

\section{Purpose}

Elevated Low-Density Lipoprotein (LDL) cholesterol is a significant risk factor for cardiovascular disease. It is estimated that $42 \%$ of females and $34 \%$ of males in the USA have elevated total cholesterol. The current mainstay of lipid lowering therapy utilizes hydroxy-methyl-glutarylcoenzyme A reductase inhibitor ('statin') medications that lower total cholesterol and LDL cholesterol by $20 \%$ and $28 \%$, respectively. However, due to the significant side effects of statin medications, many patients seek alternative therapies to help manage their hypercholesterolemia. Red Yeast Rice Monascus Purpueus has been used as a food and as an herbal medication in China for centuries. Plant Stanols and Sterols are foods that are similar in structure and function to animal cholesterol. Both these compounds have been shown in clinical studies to significantly lower LDL.

\section{Methods}

We report on a case series of 18 patients with hypercholesterolemia despite therapeutic lifestyle change through diet and exercise who took a proprietary product combining Red Yeast Rice and Plant Stanols and Sterols as a powdered shake in an effort to improve their cholesterol.

\section{Results}

Statistically significant reduction $(\mathrm{p}<0.05)$ in the following mean variables were seen: total cholesterol 19\% (46 mg/dL) and LDL 33\% (53mg/dL) after 6 weeks using the blend. There was no significant difference in BMI, triglycerides, HDL cholesterol levels, or SBP and DBP over the same period.

\section{Conclusion}

This magnitude of reduction in LDL cholesterol is significantly greater than the $28 \%$ reduction observed in the 1999 JAMA meta-analysis on the effectiveness of statin medications in lowering cholesterol levels. None of the participants in our study reported any muscle pains and no abnormal liver function tests were seen whilst taking the blend. Though this case series is limited by small sample size and study duration, the blend's significant reduction in LDL cholesterol without severe side effects indicates that this product is an effective alternative to statins.

\section{Author details \\ ${ }^{1}$ Stamford Hospital, Columbia University, Stamford, USA. ${ }^{2}$ Saced Heart University, Fairfield, USA.}

Published: 12 June 2012

doi:10.1186/1472-6882-12-S1-P144

Cite this article as: Feuerstein and Bjerke: P02.88. Powdered Red Yeast Rice and Plant Stanols and Sterols to lower cholesterol. BMC

Complementary and Alternative Medicine 2012 12(Suppl 1):P144.

Submit your next manuscript to BioMed Central and take full advantage of:

- Convenient online submission

- Thorough peer review

- No space constraints or color figure charges

- Immediate publication on acceptance

- Inclusion in PubMed, CAS, Scopus and Google Scholar

- Research which is freely available for redistribution

Submit your manuscript at www.biomedcentral.com/submit
C Biomed Central

'Stamford Hospital, Columbia University, Stamford, USA

Full list of author information is available at the end of the article

(c) 2012 Feuerstein and Bjerke; licensee BioMed Central Ltd. This is an Open Access article distributed under the terms of the Creative 